\title{
Visit to the Radiologist
}

Johanna Shapiro, PhD

Department of Family Medicine, UC Irvine School of Medicine, Orange, CA, USA.

J Gen Intern Med 26(3):351

DOI: $10.1007 / \mathrm{s} 11606-010-1601-9$

( ) The Author(s) 2010. This article is published with open access at Springerlink.com

It's like getting ready for a first date only different

Then I chose high heels hoping for a sexy sway Now I put on sensible shoes to appear a person of substance who deserves to live Then I researched football and other sports I knew boys liked so I'd seem smart but not as smart as they were Now I research metastases to show my doctor I know something but not as much as he does Then I applied liner and mascara drawing bedroom eyes Now I put on lipstick to prove I care about myself, so the doctor should care about me too Then I wanted to be liked

Now I want to be saved

Then I pleaded Choose me, choose me! Choose me to be your girlfriend! Now it is the same Choose me to be the patient you love the one you linger on for a moment before plunging needle into bone

Maybe it's not so different after all It's all about yearning for something just beyond reach

Open Access: This article is distributed under the terms of the Creative Commons Attribution Noncommercial License which permits any noncommercial use, distribution, and reproduction in any medium, provided the original author(s) and source are credited.

Published online December 21, 2010 